\title{
Supporting information for publication_R1
}

\section{Insights into inhibition mechanism of human pancreatic $\alpha$-amylase, a Type 2 Diabetes target, by dehydrodieugenol B isolated from Ocimum tenuiflorum}

\author{
Prasad D. Dandekar ${ }^{1}$, Amol S. Kotmale ${ }^{2}$, Shrawan R. Chavan ${ }^{2}$, Pranita P. Kadlag', Sangeeta \\ V. Sawant ${ }^{3}$, Dilip D. Dhavale ${ }^{2}$, Ameeta RaviKumar ${ }^{1 *}$ \\ ${ }^{1}$ Institute of Bioinformatics and Biotechnology, ${ }^{2}$ Garware Research Centre, Department of \\ Chemistry, ${ }^{3}$ Departmant of Bioinformatics, Savitribai Phule Pune University, Pune 411007, \\ India
}

\section{Experimental Section:}

Extraction of the bioactive component from Ocimum tenuiflorum:

The HPA inhibitor (DDEB) was purified from Ocimum tenuiflorum leaves using sequential solvent extraction as follows:

The leaves of the $O$. tenuiflorum were thoroughly cleaned, washed and crushed in presence of liquid nitrogen to obtain a powder. The powder $(100 \mathrm{~g})$ was weighed and immediately added to distilled water in the ratio of 1:4. The extraction was carried out by agitation for 8 hours at room temperature. Further, the liquid (cold water extract (CWE) $(403.08 \mathrm{ml}, 15.2 \mathrm{mg} / \mathrm{ml}$ ) was separated from solid powder by centrifugation at $8000 \mathrm{rpm}, 10$ minutes. Remaining powder was dried in shed at room temperature, which was then suspended $(16.03 \mathrm{~g})$ in water in 1:4 ratio and agitation for 3 hours at $60{ }^{\circ} \mathrm{C}$. Centrifugation of this mixture yielded hot water extract (HWE) $(61.54 \mathrm{ml}, 8 \mathrm{mg} / \mathrm{ml})$. In same way, the residual powder obtained after centrifugation was dried $(15.74 \mathrm{~g})$ and suspended in methanol in ratio of $1: 3$ and agitated for 3 hours at $60^{\circ} \mathrm{C}$. Centrifugation of this mixture yielded methanol extract (ME) $(43.08 \mathrm{ml}, 13.8 \mathrm{mg} / \mathrm{ml})$ after centrifugation. The residual powder obtained after centrifugation was dried (12.09 g) and suspended in 2-propanol in ratio of 1:3 and agitated for 3 hours at $60^{\circ} \mathrm{C}$. Centrifugation of this mixture yielded 2-propanol extract (IPE) $(27.69 \mathrm{ml}, 17 \mathrm{mg} / \mathrm{ml})$. The aqueous extracts were collected, filtered and lyophilized while organic extracts were concentrated in vacuo and stored at $-20{ }^{\circ} \mathrm{C}$ until further use. IPE fraction inhibiting $\alpha$-amylase was taken forward for further purification. All remaining extracts did not inhibit HPA.

\section{Purification of HPA inhibitor:}

The 2-propanol extract $(5 \mathrm{~g})$ exhibiting HPA inhibitory activity was subjected to column chromatography (silica gel, 100-200 mesh, column size $20 \mathrm{x} 4 \mathrm{~cm}$ ) and eluted successively with step gradients of n-Hexane and ethyl acetate (300 ml each) from 100:0 to 20:80 of nhexane: ethyl acetate followed by $100 \%$ methanol wash. These elutes were loaded on TLC silica $60 \mathrm{~F}_{254}$ plates with Hexane: Ethyl acetate $(80: 20)$ as mobile phase and spots were visualized by staining with phosphomolybdic acid reagent (figure S1). Fractions showing similar TLC spots were pooled, dried $(150 \mathrm{mg})$, reconstituted in 2-propanol to a final concentration of $3.5 \mathrm{mg} / \mathrm{ml}$ and subjected for $\alpha$-amylase inhibition assay.

Pooled fractions exhibiting $\alpha$-amylase inhibitory activity were further purified by semipreparative HPLC. The bioactive fractions were injected into ODS $\left(\mathrm{C}_{18}\right)$ reverse phase HPLC column $\left(25 \mathrm{~cm} \times 21.2 \mathrm{~mm}, 5 \mu \mathrm{m}\right.$, Ascentis ${ }^{\odot} \mathrm{C}_{18}$, Supelco Analytical $)$ connected to LC-6AD pumps and a SPD-M20A diode array detector (Shimadzu, Japan) set at $245 \mathrm{~nm}$. Elution was done with acetonitrile: water (90:10) as mobile phase with flow rate $5 \mathrm{ml} . \mathrm{min}^{-1}$. Fractions having peaks of same retention times were pooled, collected and checked for bioactivity. Solutions for inhibition assay were prepared in 2-propanol to a final concentration of 3.5 $\mathrm{mg} / \mathrm{ml}$ and subjected for $\alpha$-amylase inhibition assay. The peak purity of $\alpha$-amylase inhibiting 
HPLC peak was confirmed by analytical HPLC using ODS $\left(\mathrm{C}_{18}\right)$ column $(250$ x $4.60 \mathrm{~mm}, 5$ $\mu \mathrm{m}, 100 \AA$, Phenomenex Luna) using acetonitrile: water $(90: 10)$ as mobile phase with isocratic flow at $0.5 \mathrm{ml} \cdot \mathrm{min}^{-1}$.

\section{Structure determination of the bioactive compound: \\ Fourier Transform Infrared Spectrometry (FTIR):}

The neat, purified compound was loaded in FTIR spectrometer (Bruker Tensor 37) with attenuated total reflectance (ATR) attachment and scanned from 400 to $4,000 \mathrm{~cm}^{-1}$ with a resolution of $4 \mathrm{~cm}^{-1}$. The recorded spectrum was visualized by OPUS 6.5 software and the peak values and the assignment of probable functional groups to corresponding peak values was done comparing with standard values.

High Resolution Mass Spectrometry (HRMS):

HRMS was performed in positive ion mode on Bruker Impact HD High Resolution Mass (Bruker, Rheinstetten, Germany) fitted with an electron spray ionization (ESI) source and nitrogen $(4 \mathrm{~L} / \mathrm{min})$ as carrier gas. Capillary was set at $3500 \mathrm{~V}$, nebulizer at 0.3 bar and heater at $200^{\circ} \mathrm{C}$. Pure compound was reconstituted in $1 \mathrm{ml}$ of MS grade methanol, $20 \mu \mathrm{L}$ was injected and spectrum (m/z 50-600) recorded against intensity versus $\mathrm{m} / \mathrm{z}$ which was acquired using Compass DataAnalysis 4.2 (Bruker, Germany)

1D and 2D Nuclear Magnetic Resonance (NMR) experiments:

A sample for NMR spectroscopy was prepared by dissolving $7 \mathrm{mg}$ of $>98 \%$ pure compound in $0.7 \mathrm{ml} \mathrm{CDCl}{ }_{3} .{ }^{1} \mathrm{H}(500 \mathrm{MHz})$ and ${ }^{13} \mathrm{C}(125 \mathrm{MHz}) \mathrm{NMR}$ spectra were recorded on a Bruker Avance III HD instrument (Bruker, Rheinstetten, Germany). Tetramethylsilane (TMS) was the internal standard. Chemical shifts $(\delta)$ were referenced to the solvent peaks and then expressed in parts per million (ppm). All NMR data processing was done using software Bruker Topspin version 3.5 and MestRenova version 6.0.2-5475 (Mestrelab ResearchS. L.)

\section{Detailed structural elucidation using HRMS fragmentation, FTIR spectrum and 1D as well as 2D NMR spectra:}

The purified compound was pale yellow, semi-solid in nature. The isolated compound eluted with retention time of 7.42 minutes by HPLC and was ascertained to be $>98 \%$ pure (Figure S1). The UV spectrum of compound (Figure S2) showed $\lambda_{\max }(\mathrm{MeOH})$ at $245 \mathrm{~nm}$ suggesting the presence of an aromatic ring structure. The HRMS of the compound gave peaks at $349.1417(\mathrm{M}+\mathrm{Na})^{+}$and $327.15(\mathrm{M}+\mathrm{H})^{+}$corresponding to the molecular formula $\mathrm{C}_{20} \mathrm{H}_{22} \mathrm{O}_{4}$ (Figure 1). Based on the molecular formula, the compound has ten sites of unsaturation that are accommodated for two aromatic rings and two double bonds in the molecule. The mass spectrum also showed two low intensity peaks with $\mathrm{m} / \mathrm{z} 179.0699$ and 163.0751 which correspond to the molecular formulas $\mathrm{C}_{10} \mathrm{H}_{11} \mathrm{O}_{3}\left(\mathrm{M}^{+}\right)$and $\mathrm{C}_{10} \mathrm{H}_{11} \mathrm{O}_{2}\left(\mathrm{M}^{+}\right)$, respectively with tentatively assigned structures as shown in Figure $\mathrm{S} 3$ a,b.

The neat FTIR spectrum (Figure S4) showed a broad peak in the region 3150 to 2550 $\mathrm{cm}^{-1}$ which indicated the presence of $-\mathrm{OH}$ functionality. A weak signal at $1638 \mathrm{~cm}^{-1}$ suggested the presence of carbon-carbon double bond. Signals at 1596 and $1506 \mathrm{~cm}^{-1}$ were due to the presence of aromatic ring. The signals at 1455, 1430, 1207 and $1081 \mathrm{~cm}^{-1}$ were due to $\mathrm{C}-\mathrm{O}$ ether stretching and suggested the presence of alkyl-aryl ether $\left(\mathrm{Ph}-\mathrm{OCH}_{3}\right)$ functionality. The signals at 993 and $910 \mathrm{~cm}^{-1}$ indicated the presence of mono-substituted terminal double bond.

The ${ }^{1} \mathrm{H}$ NMR $(500 \mathrm{MHz})$ and ${ }^{13} \mathrm{C}$ NMR $(125 \mathrm{MHz})$ spectra in $\mathrm{CDCl}_{3}$ showed sharp intense signals (Figure S5 and S6). The assignments of signals to each proton and carbon were made using ${ }^{1} \mathrm{H},{ }^{13} \mathrm{C}$ NMR, DEPT and 2D NMR correlation experiments $\left({ }^{1} \mathrm{H}-{ }^{1} \mathrm{H}\right.$ COSY, ${ }^{1} \mathrm{H}-{ }^{13} \mathrm{C}$ HMBC and HSQC) and are given in Table S2. In the ${ }^{1} \mathrm{H}$ NMR spectrum, the presence of two doublets, each integrating for two hydrogens, at $\delta_{\mathrm{H}} 3.24(\mathrm{br} \mathrm{d}, J=6.7 \mathrm{~Hz})$ and $3.36(\mathrm{br} \mathrm{d}, J=6.7$ 
$\mathrm{Hz}$ ], a multiplet for four hydrogens [ $\delta_{\mathrm{H}} 5.12$ to 5.01$]$ and another multiplet for two protons $\left[\delta_{\mathrm{H}}\right.$ 6.01 to 5.85] indicated the presence of two allyl $\left(-\mathrm{CH}_{2}-\mathrm{CH}=\mathrm{CH}_{2}\right)$ functionalities. The chemical shifts of $\mathrm{sp}^{3}$ methylene protons at $\delta_{\mathrm{H}} 3.3$ indicated that allyl functionalities are attached to the aromatic rings confirming the presence of two aromatic allyl $\left(-\mathrm{CH}_{2}-\mathrm{CH}=\mathrm{CH}_{2}\right)$ groups. In the aromatic region, two mutually metacoupled protons at high field region $\delta_{\mathrm{H}} 6.40(\mathrm{~d}, J=1.8 \mathrm{~Hz}$, $1 \mathrm{H})$ and $6.49(\mathrm{~d}, J=1.8 \mathrm{~Hz}, 1 \mathrm{H})]$ suggested the 1,2,4,6 tetra-substituted (three trioxygenated and one allyl) phenyl ring A (Figure S3c). Two singlets at $\delta_{\mathrm{H}} 3.89$ and 3.86 showed the presence of two methoxy groups. In addition, the aromatic region showed signals, each corresponding to one proton, as orthro- and meta-coupled doublet of doublet $\delta_{\mathrm{H}} 6.71$ (dd, $J=$ $8.1,2.0 \mathrm{~Hz})$, one meta-coupled doublet $\delta_{\mathrm{H}} 6.79(\mathrm{~d}, J=1.9 \mathrm{~Hz})$ and one ortho-coupled doublet $\delta_{\mathrm{H}} 6.88(\mathrm{~d}, J=8.1 \mathrm{~Hz})$ suggesting the 1, 2, 4 trisubstituted dioxygenated and allylated phenyl ring B (Figure S3c). The ${ }^{13} \mathrm{C}$ (Figure S6) and DEPT NMR data (Figure S7) showed presence of two methoxy groups (55.98 and $56.23 \mathrm{ppm}$ ); two methylene carbons (39.96 and 39.91). In addition, five aromatic carbons $(120.83,119.48,112.89,111.86,107.25)$ and seven aromatic quaternary carbons were observed. The ${ }^{1} \mathrm{H}$ and ${ }^{13} \mathrm{C}$ NMR data suggested that the compound has a dehydrodieugenol type of skeleton having two methoxy groups, two allyl groups and a hydroxyl group.

For assigning positions of groups in aromatic rings, 2D-NMR correlation experiments were performed. In the 2D COSY spectrum (Figure S8) the cross peak between $\delta_{\mathrm{H}} 6.7 \mathrm{H}-5$ ' and $\delta_{\mathrm{H}} 6.88 \mathrm{H}-6$ ' suggested the aromatic ring $\mathrm{B}$ hydrogens as ortho to each other. The cross peaks between $\delta_{\mathrm{H}} 3.36 \mathrm{H}-7^{\prime}$ and $\delta_{\mathrm{H}} 5.96 \mathrm{H}-8$ ', $\delta_{\mathrm{H}} 5.96 \mathrm{H}-8^{\prime}$ and $5.08 \mathrm{H}-9$ ' showed the connectivity through bonds. Similarly, $\delta_{\mathrm{H}} 3.24 \mathrm{H}-7$ and $\delta_{\mathrm{H}} 5.87 \mathrm{H}-8$ and $\delta_{\mathrm{H}} 5.01 \mathrm{H}-9$ are connected through bonds. These ${ }^{1} \mathrm{H}-{ }^{13} \mathrm{C}$ single bond correlations are shown in the Table $\mathrm{S} 1$, Figure S9. The positions of other functionalities and hydrogens were determined by HMBC (Figure S10), HSQC (Figure S11) and NOESY (Figure S12) spectra. The HMBC spectrum (Figure S10) gave ${ }^{1} \mathrm{H}-{ }^{13} \mathrm{C}$ multiple bond correlations (Table S2 and Figure S9).

In the 2D NOESY spectrum (Figure S12), the H-7 methylene protons of allyl group of ring A showed NOESY cross peaks with both meta-coupled aromatic protons at $\delta_{\mathrm{H}} 6.49$ and 6.40 , while C-7' methylene protons of ring B showed NOESY cross peaks with meta-coupled aromatic doublet at 3' and doublet of doublet at 5'. Similarly, the methoxy protons at $\delta_{\mathrm{H}} 3.86$ showed NOESY cross peak corresponding to meta-coupled proton at $\mathrm{H}-3$ ' of ring B $\left(\delta_{\mathrm{H}} 6.80\right)$. Whereas methoxy protons at $\delta_{\mathrm{H}} 3.89$ showed NOESY cross peak to meta-coupled proton $\left(\delta_{\mathrm{H}}\right.$ 6.40) corresponding to $\mathrm{H}-4$ of ring $\mathrm{A}$. This data indicated that in ring $\mathrm{A}$, hydroxy, methoxy and allyl groups are at 2, 3 and $5^{\text {th }}$ positions respectively. Whereas, in ring B methoxy group is at 2' and allyl group is at 4 ' position thus supporting structure $1 \mathrm{c}$. The given ${ }^{1} \mathrm{H}$ and ${ }^{13} \mathrm{C} N M R$ spectral data are well in agreement with dehydrodieugenol B (DDEB) isolated from Nectandra leucantha reported earlier ${ }^{\mathrm{S} 1}$. However, to date, there is no report of isolation of dehydrodieugenol B from Ocimum tenuiflorum.

${ }^{1} \mathrm{H}$ NMR $\left(500 \mathrm{MHz}, \mathrm{CDCl}_{3}\right) \delta 6.88(\mathrm{~d}, \mathrm{~J}=8.1 \mathrm{~Hz}, 1 \mathrm{H}), 6.79(\mathrm{~d}, J=2.0 \mathrm{~Hz}, 1 \mathrm{H}), 6.71(\mathrm{dd}, J=$ $8.1,2.0 \mathrm{~Hz}, 1 \mathrm{H}), 6.49(\mathrm{~d}, J=1.8 \mathrm{~Hz}, 1 \mathrm{H}), 6.40(\mathrm{~d}, J=1.8 \mathrm{~Hz}, 1 \mathrm{H}), 6.01-5.91(\mathrm{~m}, 1 \mathrm{H}), 5.89-$ $5.85(\mathrm{~m}, 1 \mathrm{H}), 5.10(\mathrm{dt}, J=3.0,1.7 \mathrm{~Hz}, 1 \mathrm{H}), 5.08(\mathrm{dd}, J=3.4,1.5 \mathrm{~Hz}, 1 \mathrm{H}), 5.05-5.02(\mathrm{~m}, 1 \mathrm{H})$, $5.01(\mathrm{t}, J=1.5 \mathrm{~Hz}, 1 \mathrm{H}), 3.89(\mathrm{~s}, 3 \mathrm{H}), 3.86(\mathrm{~s}, 3 \mathrm{H}), 3.36(\mathrm{~d}, J=6.7 \mathrm{~Hz}, 2 \mathrm{H}), 3.24(\mathrm{~d}, J=6.7 \mathrm{~Hz}$, $2 \mathrm{H})$ 
${ }^{13} \mathrm{C}$ NMR $\left(125 \mathrm{MHz}, \mathrm{CDCl}_{3}\right) \delta 150.38,147.83,144.40,144.20,137.43,137.28,136.41$, $135.18,131.06,120.83,119.48,115.99,115.73,112.89,111.86,107.25,56.23,55.98,39.96$, 39.91

${ }^{1} \mathrm{H}-{ }^{13} \mathrm{C}$ multiple bond correlations: (also refer Figure S9 and Table S1)

H-4 $\left(\delta_{\mathrm{H}} 6.49\right)$ showed correlations to $\mathrm{C}-3,5,6,2$ and $7\left(\delta_{\mathrm{C}} 147.83,135.19,111.86,131.06\right.$, 39.93); H-6 $\left(\delta_{\mathrm{H}} 6.40\right)$ showed correlations to C-1, 4, 5 and $7\left(\delta_{\mathrm{C}} 144.40,107.25,135.18\right.$, $39.93) ; \mathrm{H}-7\left(\delta_{\mathrm{H}} 3.24\right)$ showed correlations to C-4, 6 and $8\left(\delta_{\mathrm{C}} 107.24,111.86,137.43\right) ; \mathrm{H}-10$ $\left(\delta_{\mathrm{H}} 3.89\right)$ showed correlation to $\mathrm{C}-3\left(\delta_{\mathrm{C}} 147.83\right)$; H-3' $\left(\delta_{\mathrm{H}} 6.79\right)$ showed correlations to C-2', 4', 5' and 7' $\left(\delta_{\mathrm{C}} 150.38,136.41,120.8,39.96\right) ; \mathrm{H}-5$ ' $\left(\delta_{\mathrm{H}} 6.71\right)$ showed correlations to C-1', 3', $6^{\prime}$ ' and 7' $\left(\delta_{\mathrm{H}} 144.20,112.8,119.40,39.96\right) ; \mathrm{H}^{-7}$ ' $\left(\delta_{\mathrm{H}} 3.36\right)$ showed correlations to C-3', 5' and $8^{\prime}\left(\delta_{\mathrm{C}} 112.89,120.83,137.28\right) ; \mathrm{H}-10^{\prime}\left(\delta_{\mathrm{H}} 3.86\right)$ showed correlation to C-2' $\left(\delta_{\mathrm{C}} 150.38\right)$ and so on.

\section{Enzyme inhibition assay:}

Enzyme inhibition assay was performed using DNSA method ${ }^{\mathrm{S} 2}$. Reaction mixture containing assay buffer $(500 \mu \mathrm{l}$ of $0.02 \mathrm{M}$ sodium phosphate buffer of $\mathrm{pH} 6.9$ with $6 \mathrm{mM}$ sodium chloride), enzyme (0.04 units of HPA) and extracts at concentration from 0.1-1.5 mg ml $\mathrm{m}^{-1}(\mathrm{w} / \mathrm{v})$ was pre-incubated at $37^{\circ} \mathrm{C}$ for $10 \mathrm{~min}$. After pre-incubation, substrate $(500 \mu \mathrm{l}$ of $1 \%(\mathrm{w} / \mathrm{v})$ starch solution) was added to the reaction mixture, incubated further for $15 \mathrm{~min}$ and the reaction was terminated by addition of $1 \mathrm{ml}$ of DNSA reagent. The tubes were kept in boiling water bath for 5 minutes, cooled to room temperature followed by addition of $50 \mu \mathrm{l}$ of the generated colored product from each tube to $250 \mu \mathrm{l}$ of distilled water in 96 well plate and absorbance was measured at $540 \mathrm{~nm}$. The reaction control without any solvent or plant extract represented $100 \%$ enzyme activity and did not contain any extract or DDEB. Appropriate controls with plain solvent (2-propanol), extract and DDEB controls and substrate control (substrate without enzyme) were also assayed and used to correct the values. Acarbose was used as a positive control. Calculation of \% HPA inhibition due to extract and DDEB were calculated as follows:

$\%$ Relative enzyme activity $=($ Enzyme activity of test - enzyme activity of control $) * 100$

$\%$ inhibition $=(100-\%$ relative enzyme activity $)$

\section{Circular Dichroism (CD) spectroscopy:}

$\mathrm{CD}$ analysis of HPA, in presence and absence of DDEB were recorded in the near-UV (250 $320 \mathrm{~nm}$ ) and far-UV (195 to $250 \mathrm{~nm}$ ) regions using J-815 spectrometer (Jasco International Co. Ltd., Japan). The quartz cuvette (0.1-cm path length) containing 50-100 $\mu$ g of HPA in 20 $\mathrm{mM}$ sodium phosphate buffer $(\mathrm{pH} 6.9)$ was pre-incubated for $10 \mathrm{~min}$ at $25 \mathrm{C}$ with pure compound its $K_{i}$ ' prior to recording spectra. Instrument parameters were set as follows: temperature $=25^{\circ} \mathrm{C}$, Bandwidth $=1 \mathrm{~nm}$ and path length of cuvette $=1 \mathrm{~mm}$. Spectrum of HPA without inhibitor was recorded and compared with the spectrum of HPA with inhibitor. Appropriate buffer controls were also scanned and final results were corrected accordingly.

Molar ellipticity was calculated using the following equation:

$[\Theta]=\Theta / 10 * c^{*} 1$

Where

$[\Theta]=$ molar ellipticity, expressed in degrees $\cdot \mathrm{cm}^{2} \cdot$ decimole $^{-1}$,

$\Theta=$ value of ellipticity given by the instrument

$\mathrm{c}=$ concentration of the test solution in mole litre $^{-1}$,

$1=$ optical pathlength of the cell in centimeter. 


\section{Isothermal Titration Calorimetry (ITC)}

Isothermal calorimetry was carried out using Isothermal Titration Microcalorimeter (Microcal PEAQ-ITC, Malvern instruments Ltd., UK). Reference cell was filled with $250 \mu 1$ of $20 \mathrm{mM}$ sodium phosphate buffer of $\mathrm{pH} 6.9$ while in sample cell, $250 \mu \mathrm{l}$ of $20 \mathrm{mM}$ sodium phosphate buffer of $\mathrm{pH} 6.9$ having $12.5 \mu \mathrm{M}$ HPA was added slowly avoiding introduction of air bubbles. The instrument syringe was loaded with $20 \mathrm{mM}$ sodium phosphate buffer, $\mathrm{pH} 6.9$ containing $250 \mu \mathrm{M}(40 \mu \mathrm{l})$ of DDEB. Injections of DDEB solution were performed automatically using a run program of following parameters: temperature $=25^{\circ} \mathrm{C}(298.15 \mathrm{~K})$, DP (Differential Power) $=10 \mu \mathrm{cal} . \mathrm{sec}^{-1}$, syringe RPM $=720$, total injections $=19$ (first injection of $0.8 \mu$ followed by 18 injections injecting $2 \mu \mathrm{l}$ of DDEB in sample cell), interval between injections $=120$ seconds. The above experiment was repeated with $12.5 \mu \mathrm{M}$ HPA pre-incubated in sample cell with $2.6 \mathrm{uM}$ acarbose at $25^{\circ} \mathrm{C}$ for 5 minutes followed by injections of inhibitor through instrument syringe as above. Results of both experiments were analyzed by Malvern PAQC Analysis software (Malvern instruments Ltd., UK) for baseline correction and calculations of $\mathrm{n}, K_{d}$ and thermodynamic parameters $(\Delta \mathrm{G}, \Delta \mathrm{H}$ and $\mathrm{T} \Delta \mathrm{S})$.

\section{Molecular docking studies}

To standardize and validate the docking parameters, a docking simulation of HPA with a known inhibitor, acarbose (PDB ID: 1B2Y) was performed ${ }^{\mathrm{S} 3}$ and the docked structure was analysed and compared with the co-crystal structure so as to fine-tune the parameters to achieve accurate binding site and pose. Prior to docking simulation, the structures of HPA and DDEB were prepared using the Protein Preparation Wizard and Ligprep tools ${ }^{\mathrm{S} 4}$ in Maestro ${ }^{\mathrm{S} 5}$. The OPLS2005 ${ }^{\mathrm{S} 6}$ force field was used. SiteMap tool (version 2.3) ${ }^{\mathrm{S} 7}$, in Glide suite was used to identify surface pockets on HPA structure. After grid generation, docking simulations were performed using the Standard Precision (SP) mode of Glide (Grid-based Ligand Docking with Energetics) module in Schrodinger ${ }^{\mathrm{S} 8}$. Docking simulations of two low energy conformers of the inhibitor at each of the predicted binding sites were performed.

The binding free energies of the top ranking docked complexes were computed using MMGBSA (Molecular Mechanics- the Generalized Born-model and Solvent Accessibility) method $^{\mathrm{S} 9, \mathrm{~S} 10}$. Protein ligand interactions were analysed by using Ligand Interaction Diagram utility in Glide and LIGPLOT version 4.5.3 ${ }^{\mathrm{S} 11}$. The docking protocol is summarized in Figure S15. 
Supplementary Figures:

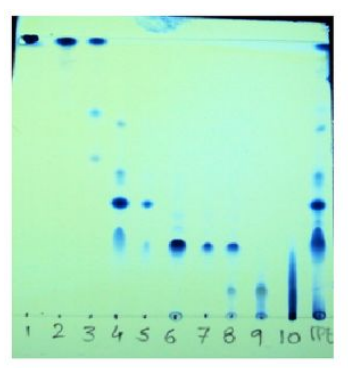

A

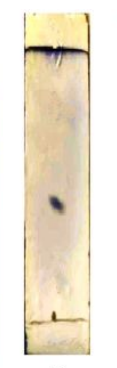

B

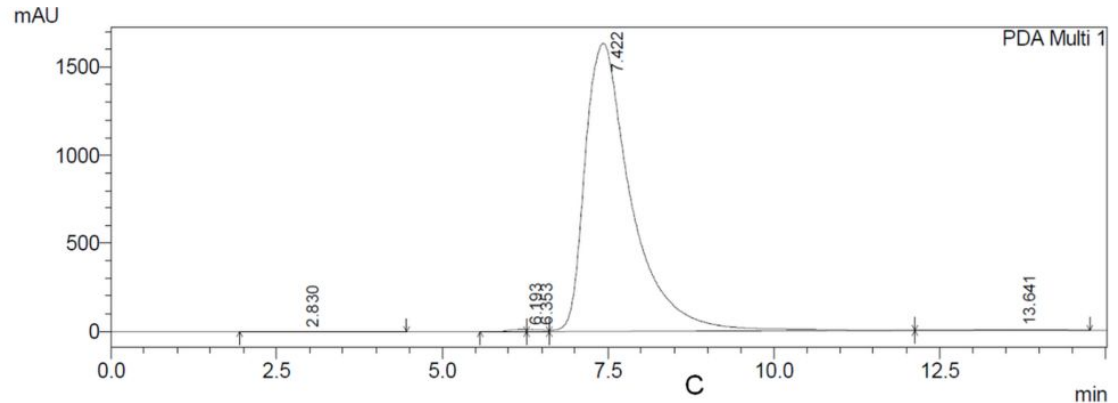

Figure S1: TLC profiles of (A) silica gel 100-200 mesh column fractions (to be seen with table S1 for inhibition)and (B) purified compound after HPLC with HPLC Profile of pure compound in $(\mathbf{C})$.

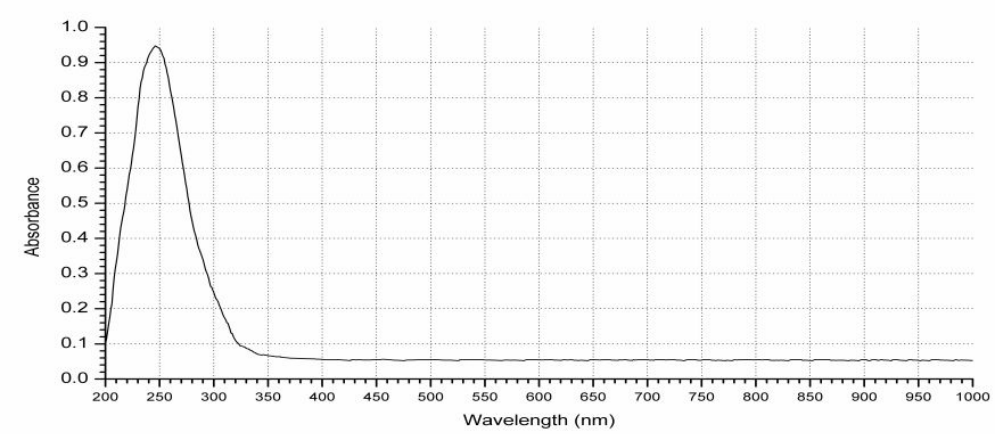

Figure S2: UV spectrum of the pure compound

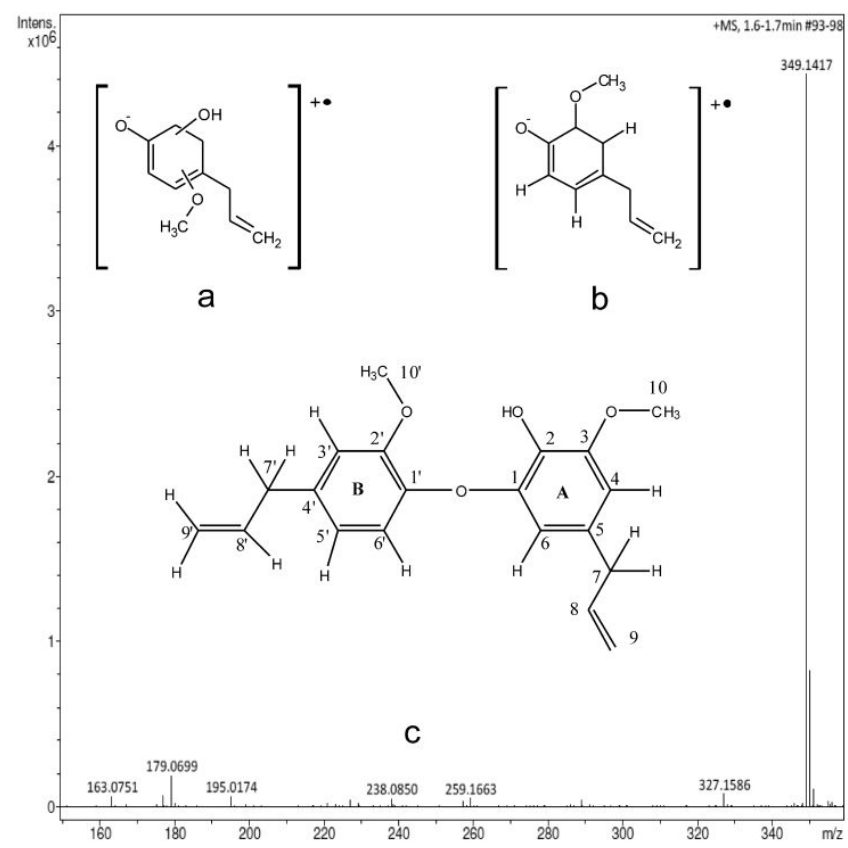

Figure S3: HRMS spectrum with structures of two mass fragments [(a) and (b)] and pure compound (c). 


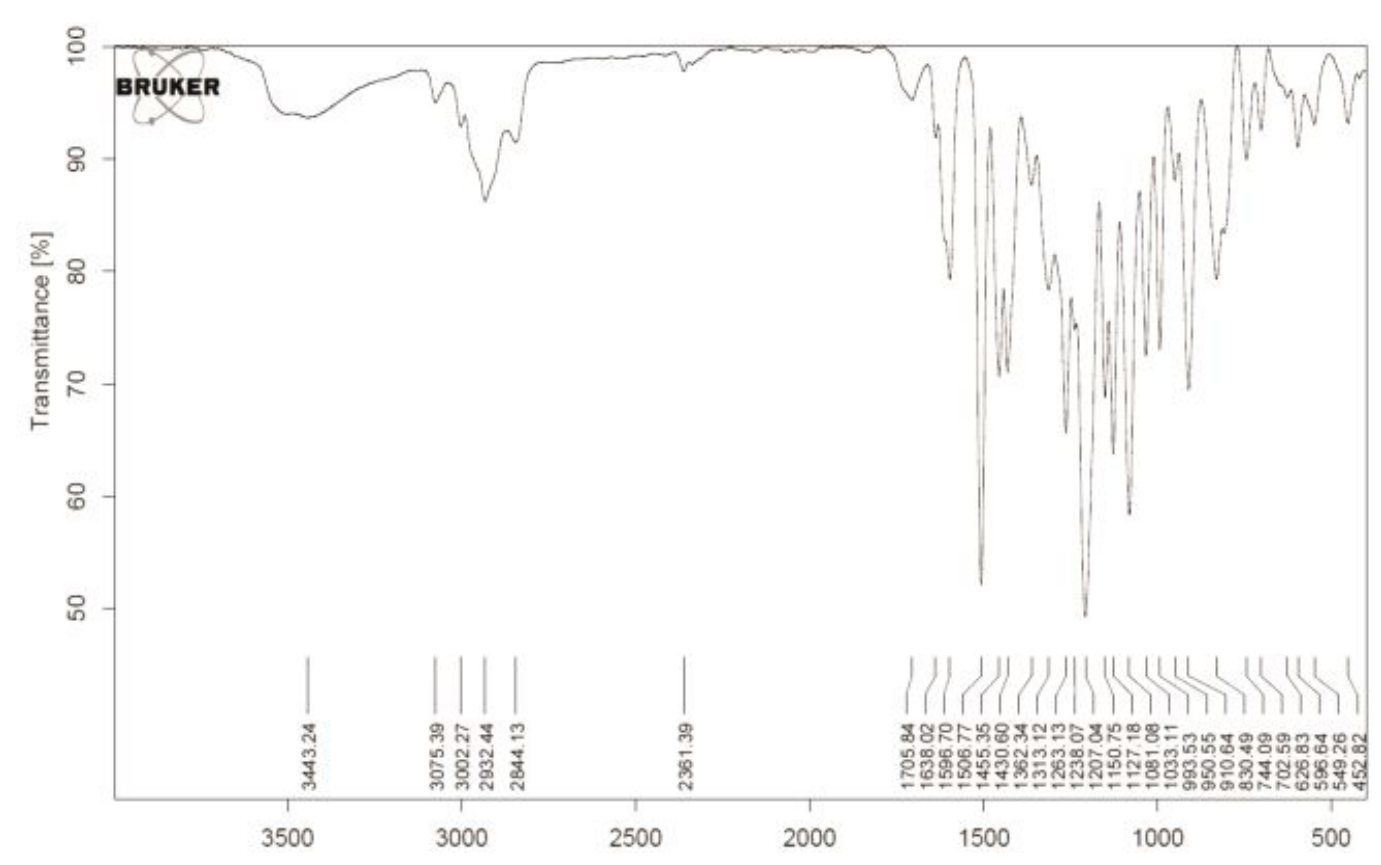

Figure S4: FTIR spectrum of the pure compound

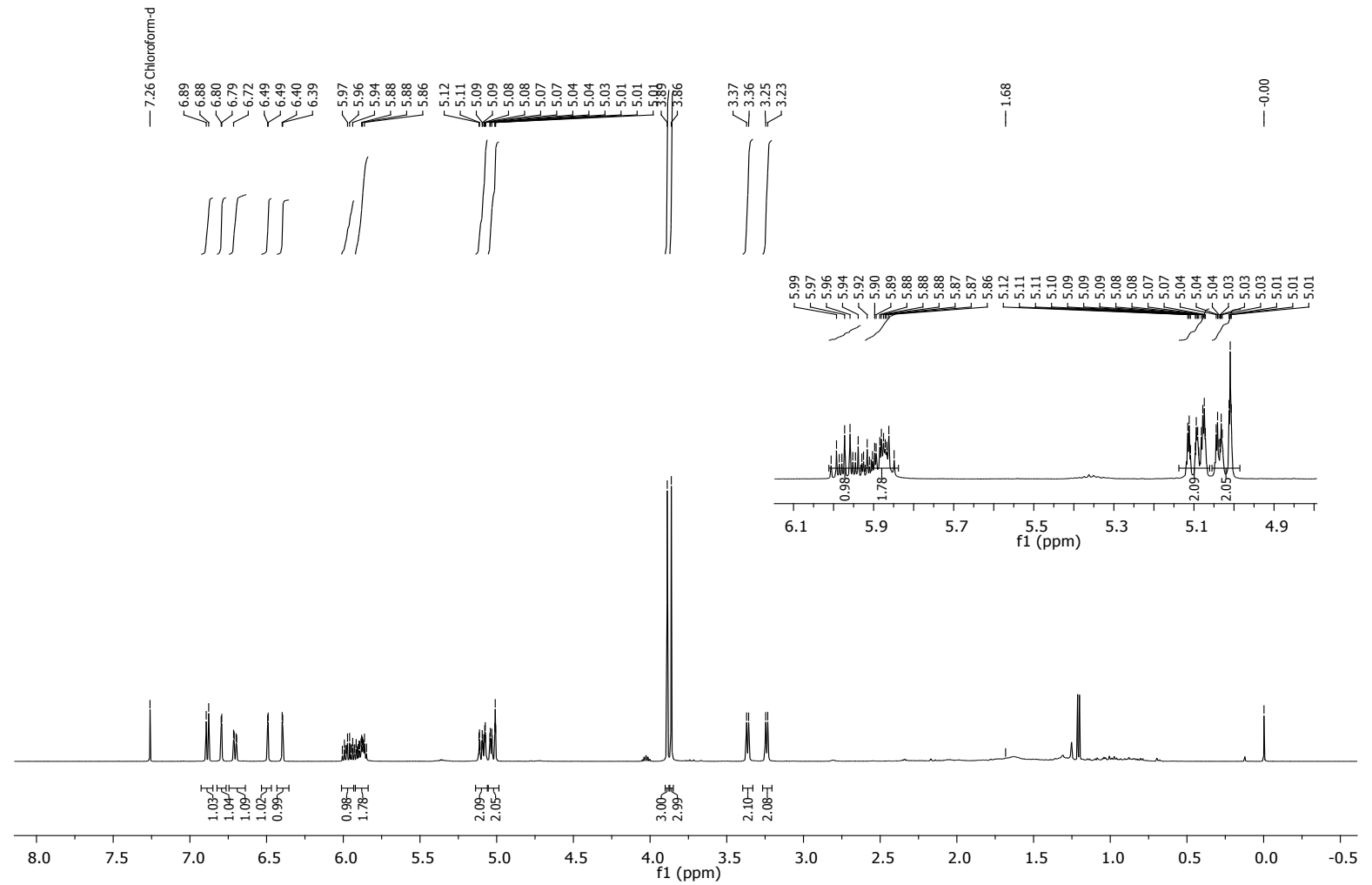

Figure S5: ${ }^{1} \mathrm{H}$ NMR spectrum of inhibitor 

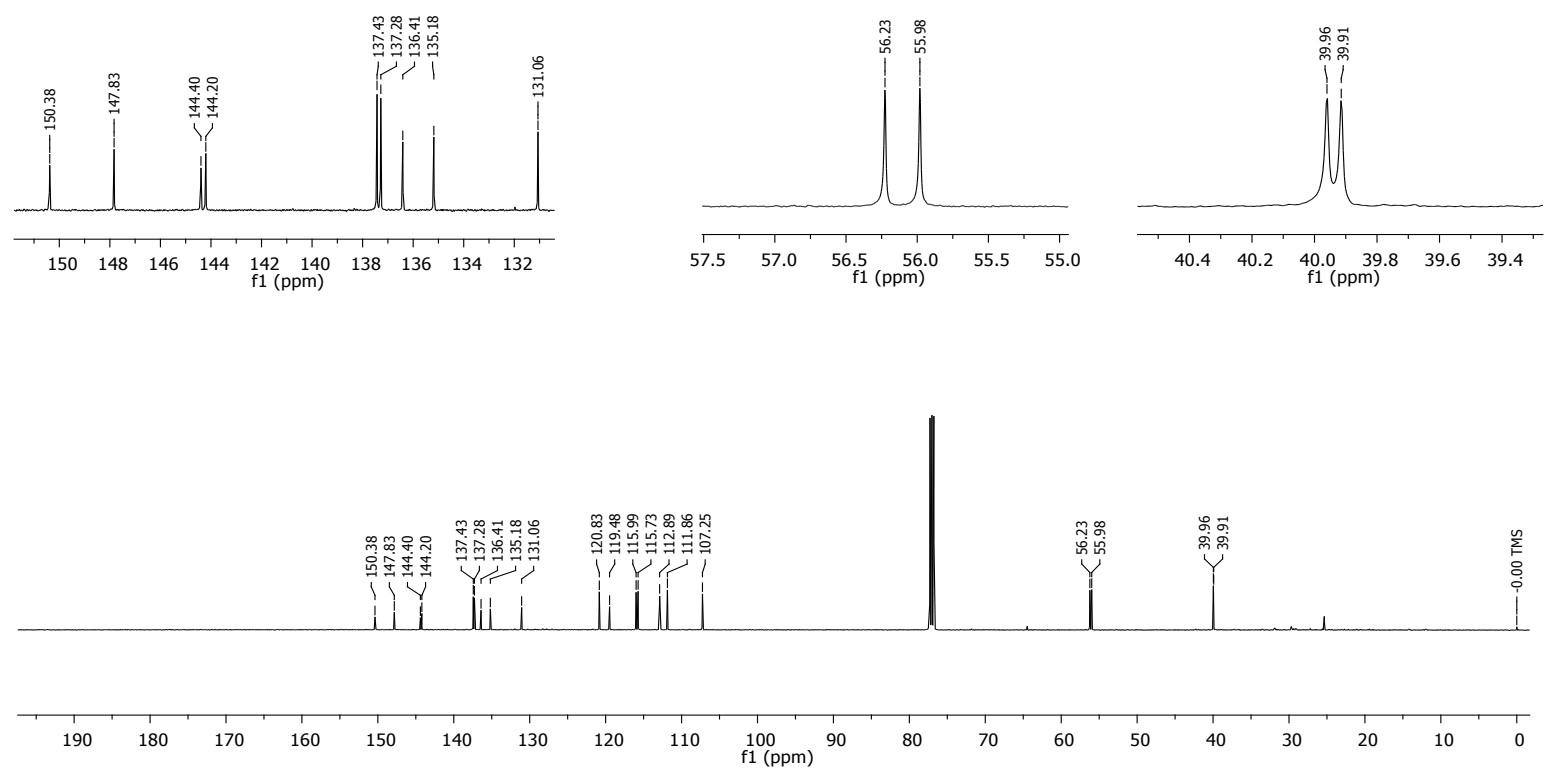

Figure S6: ${ }^{13} \mathrm{C}$ NMR spectrum of inhibitor 


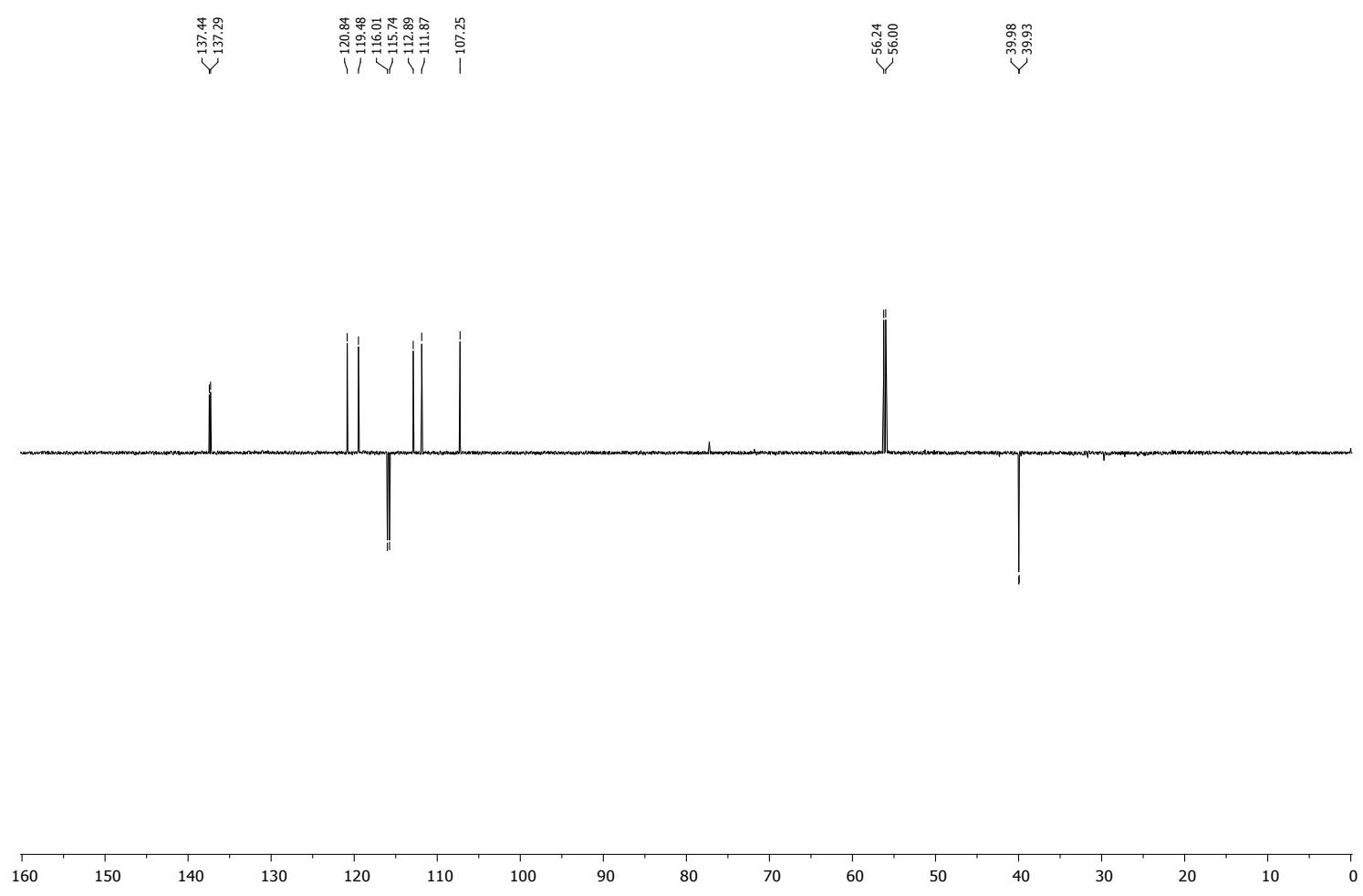

Figure S7: DEPT NMR spectrum of inhibitor 


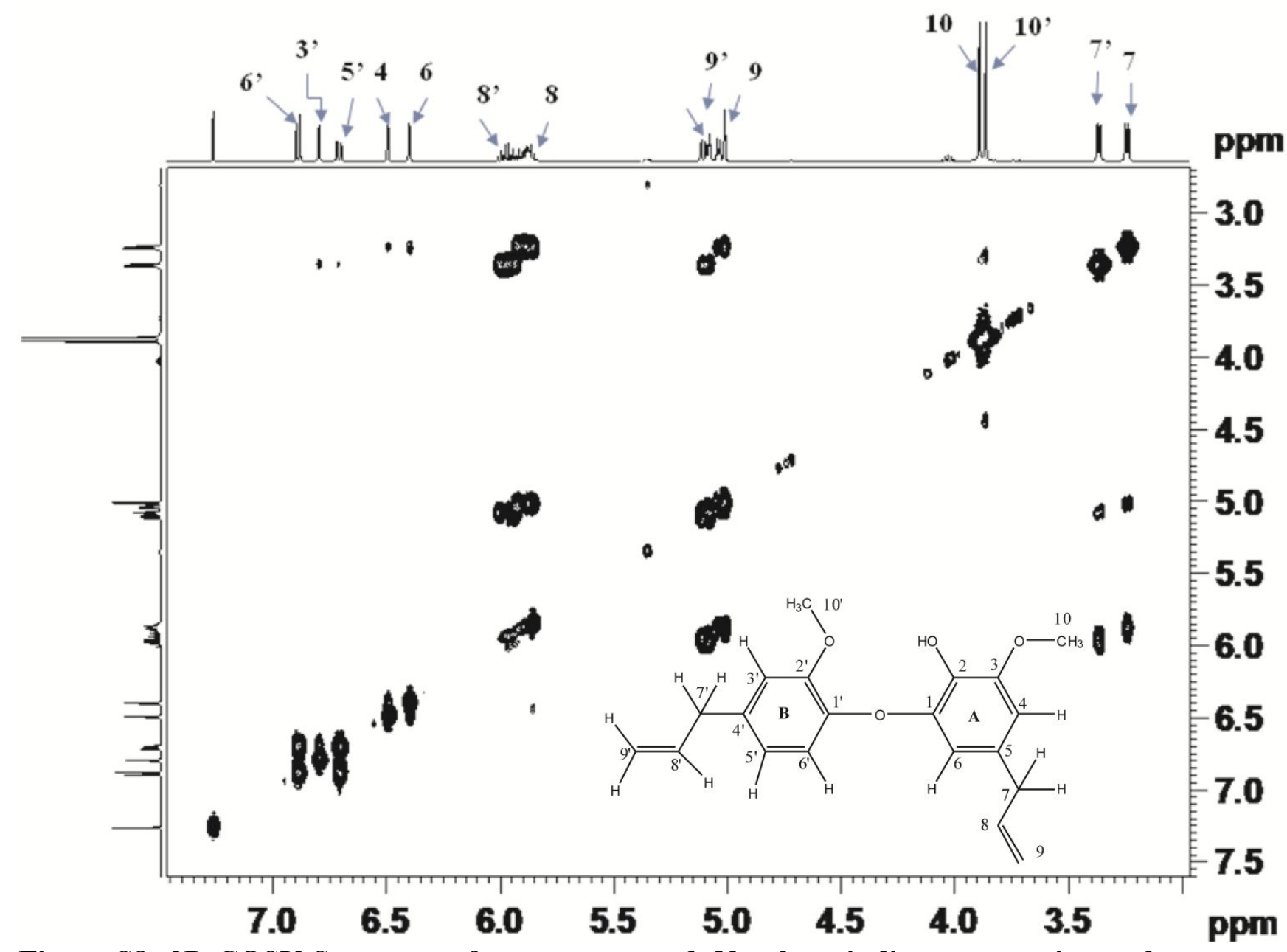

Figure S8: 2D COSY Spectrum of pure compound. Numbers indicate respective carbon atoms in the assigned structure (inset)

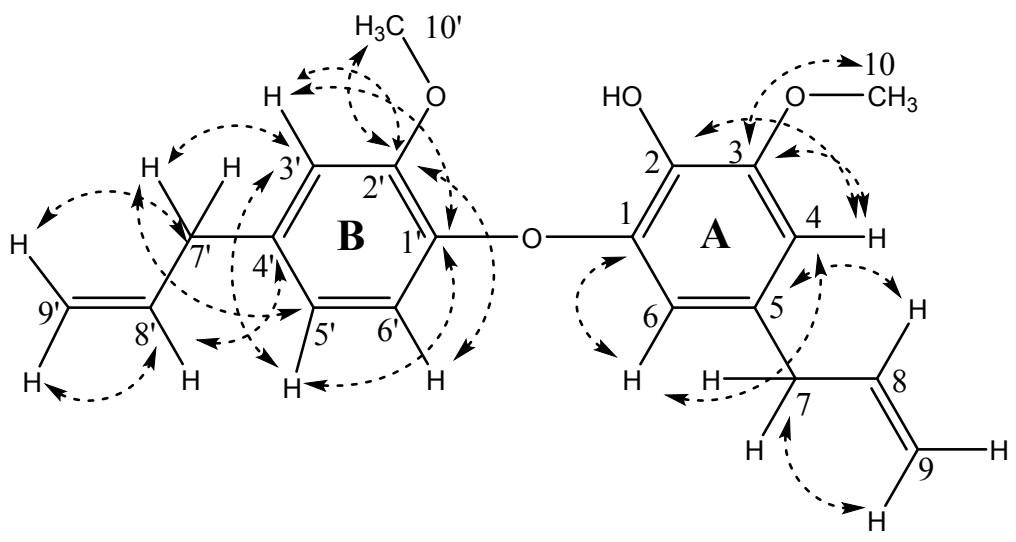

Figure S9: Key HMBC Correlations of protons and carbons of compound. Numbers indicate respective carbon atoms in the assigned structure. The hydrogen-carbon correlations atoms are indicated by dashed arrows. 


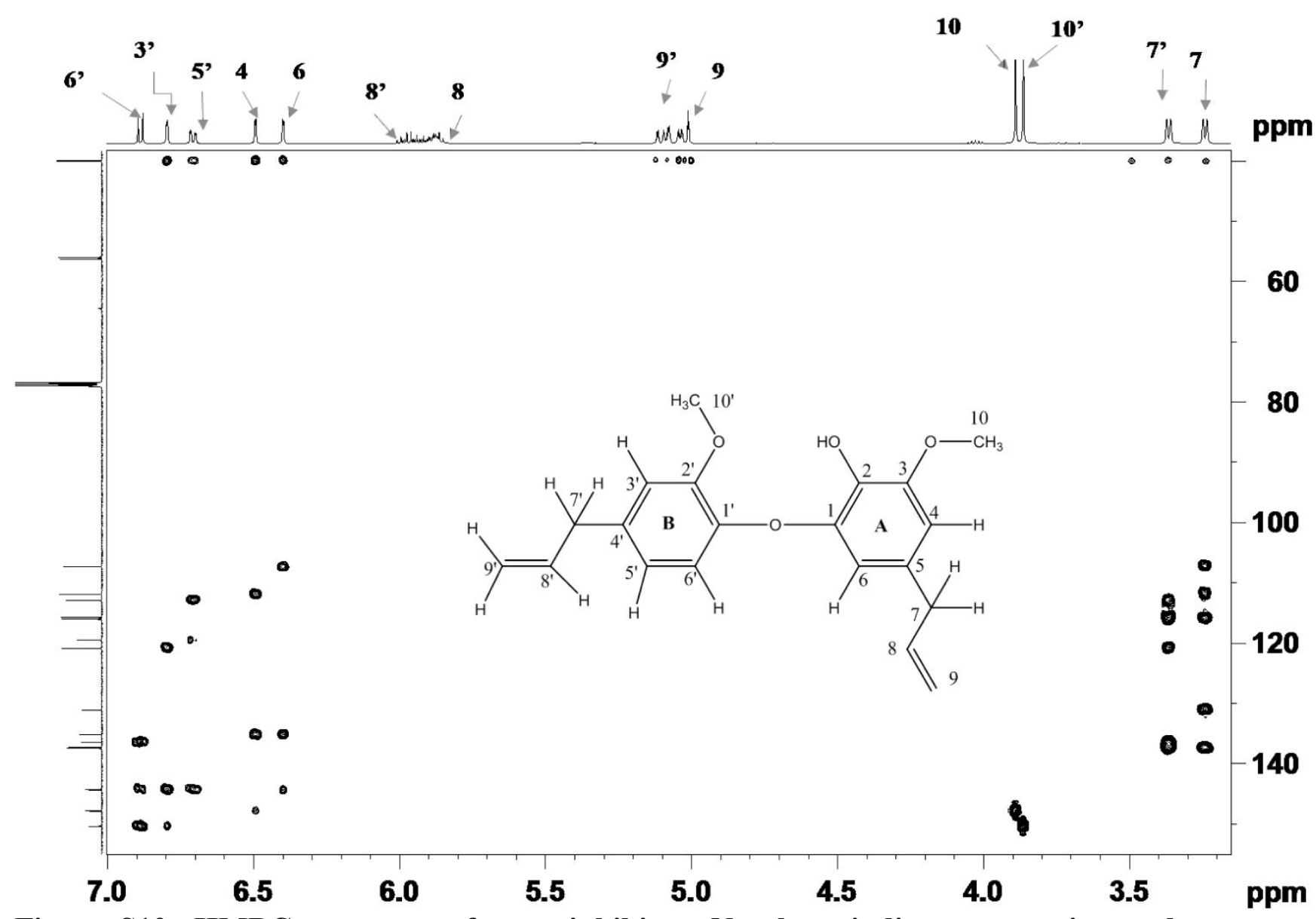

Figure S10: HMBC spectrum of pure inhibitor. Numbers indicate respective carbon atoms in the assigned structure (inset) 


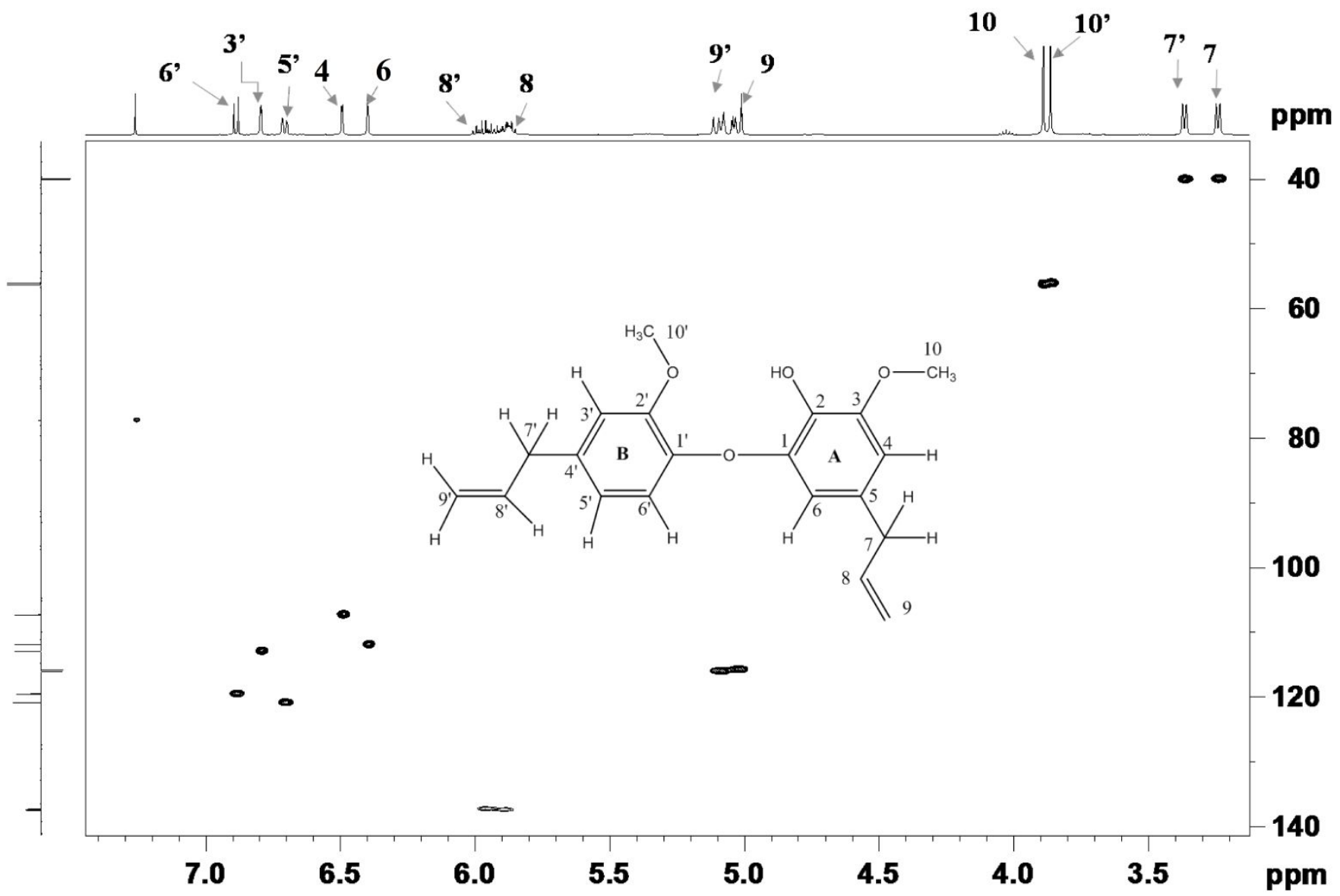

Figure S11: HSQC spectrum of pure inhibitor. Numbers indicate respective positions of carbon atoms in the assigned structure (inset) 

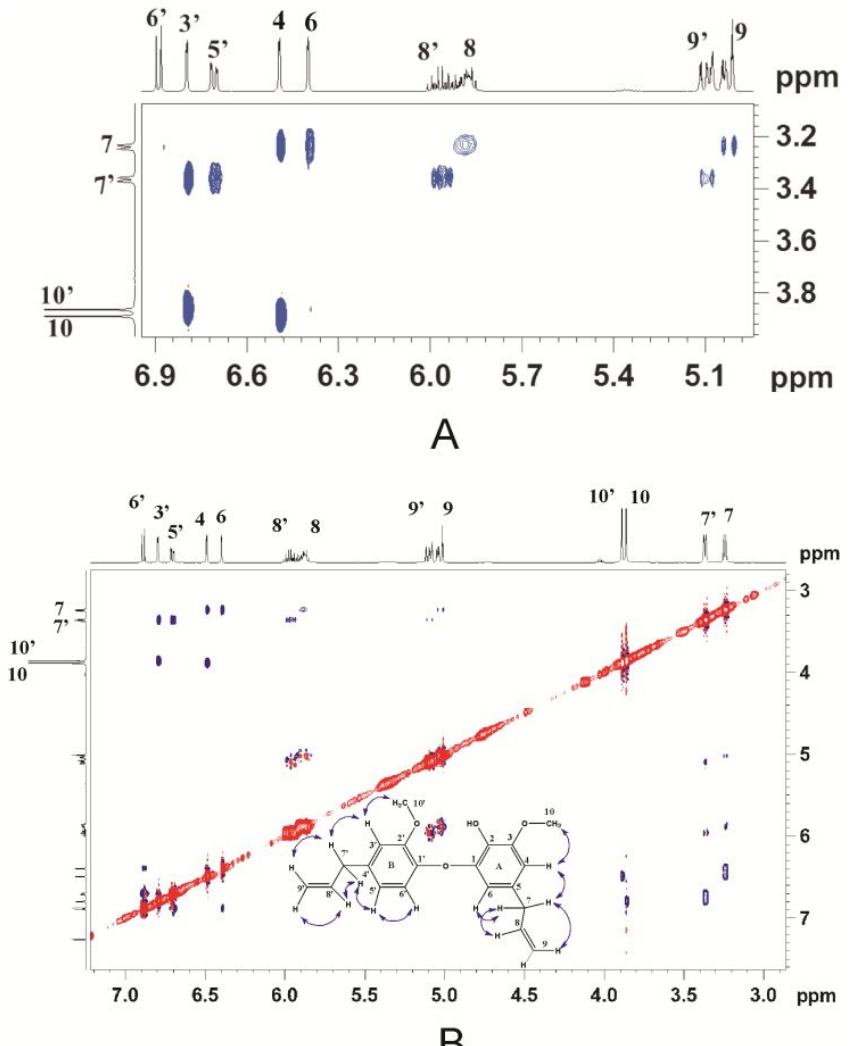

Figure S12 Zoomed in portion (A) of full NOSEY spectrum (B) of pure compound showing correlation peaks. Numbers indicate respective carbon atoms in the assigned structure 


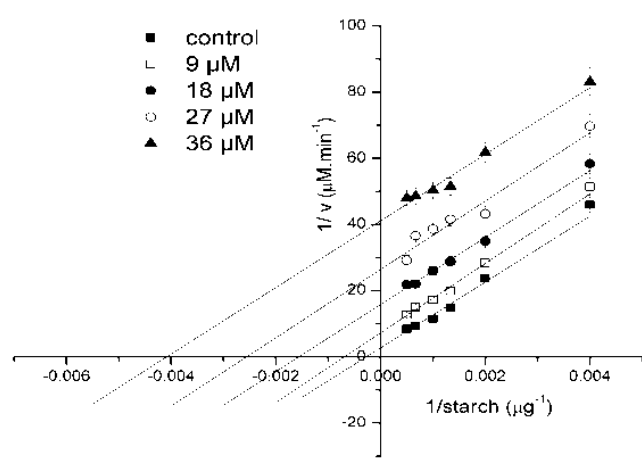

A

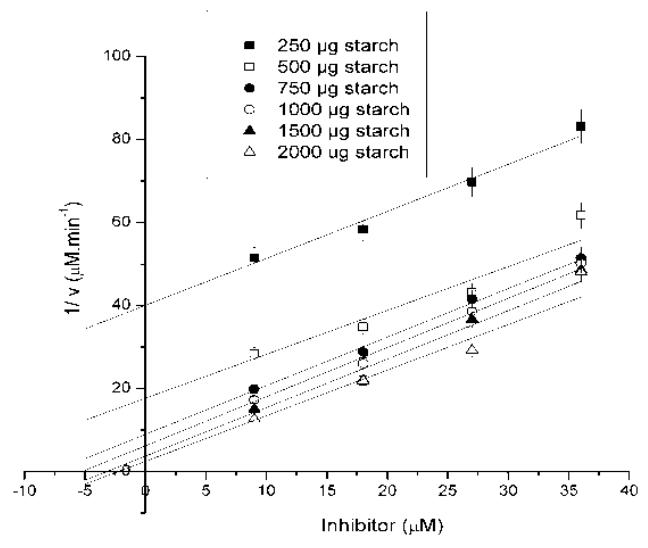

C
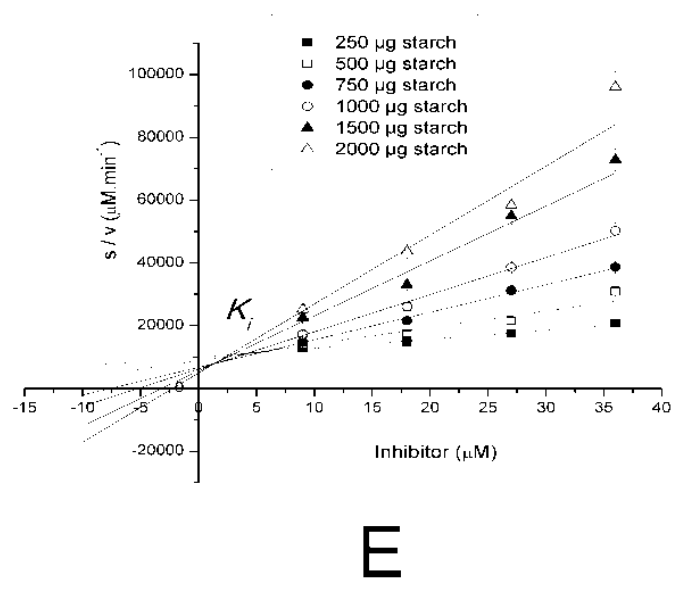

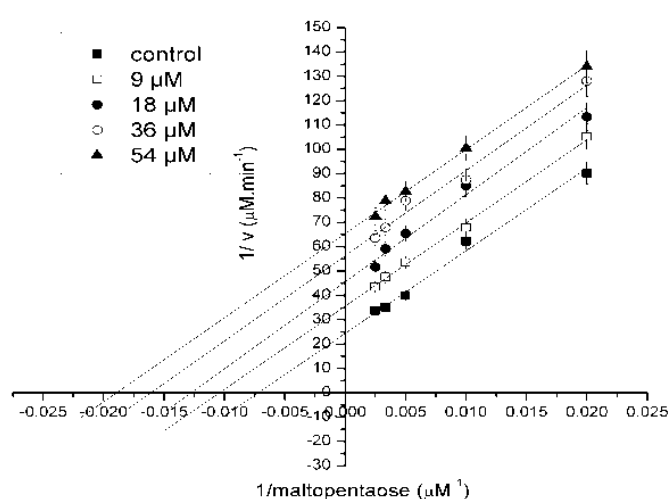

B

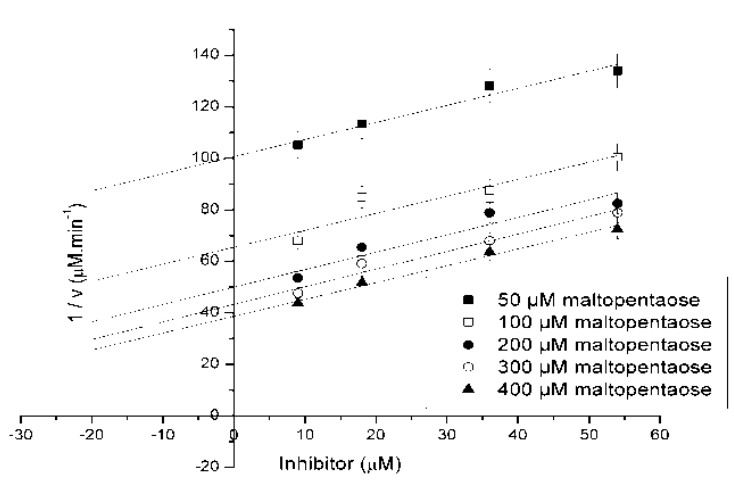

D

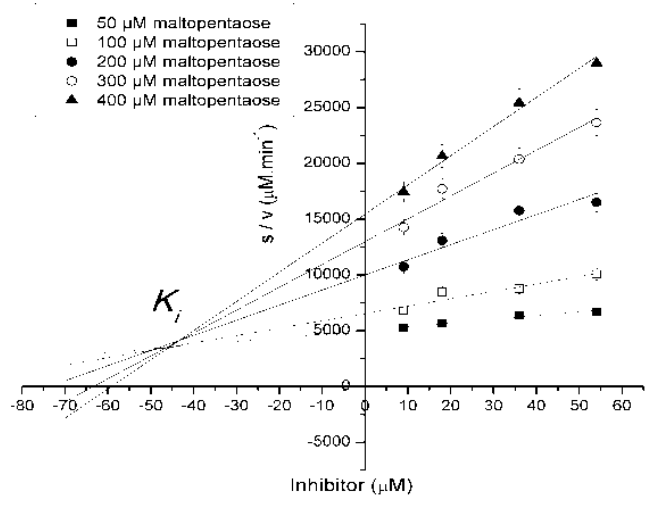

$\mathrm{F}$

Figure S13:Inhibition kinetics of DDEB: $A$ and $B$ are Lineweaver-Burk, $C$ and $D$ are Dixon and $E$ and $F$ are Cornish-Bowden plots with starch (A, $C \& E$ ) and maltopentaose $(B, D \& F)$ as substrates respectively.Various concentrations of the inhibitor, starch and maltopentaose are indicated in the respective legend entries. 


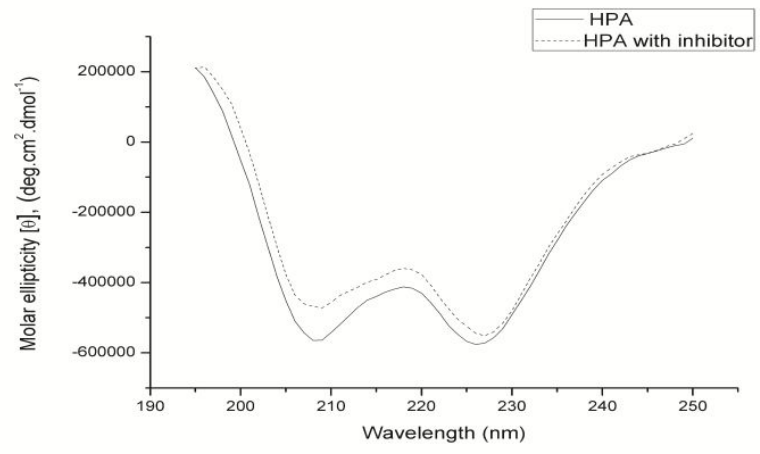

A

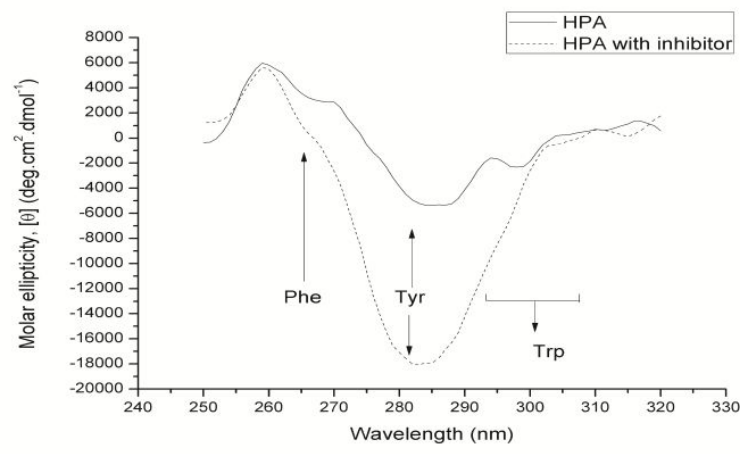

B

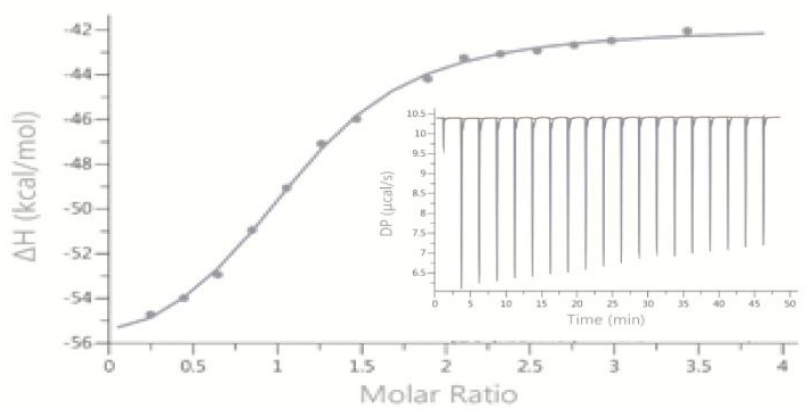

C

Figure S14: Ligand Binding study. (A) Far and (B) near UV CD spectra of HPA with (‥) and (-) without DDEB and (C) Fitted ITC curve of HPA-DDEB binary complex with isotherm in inset. 


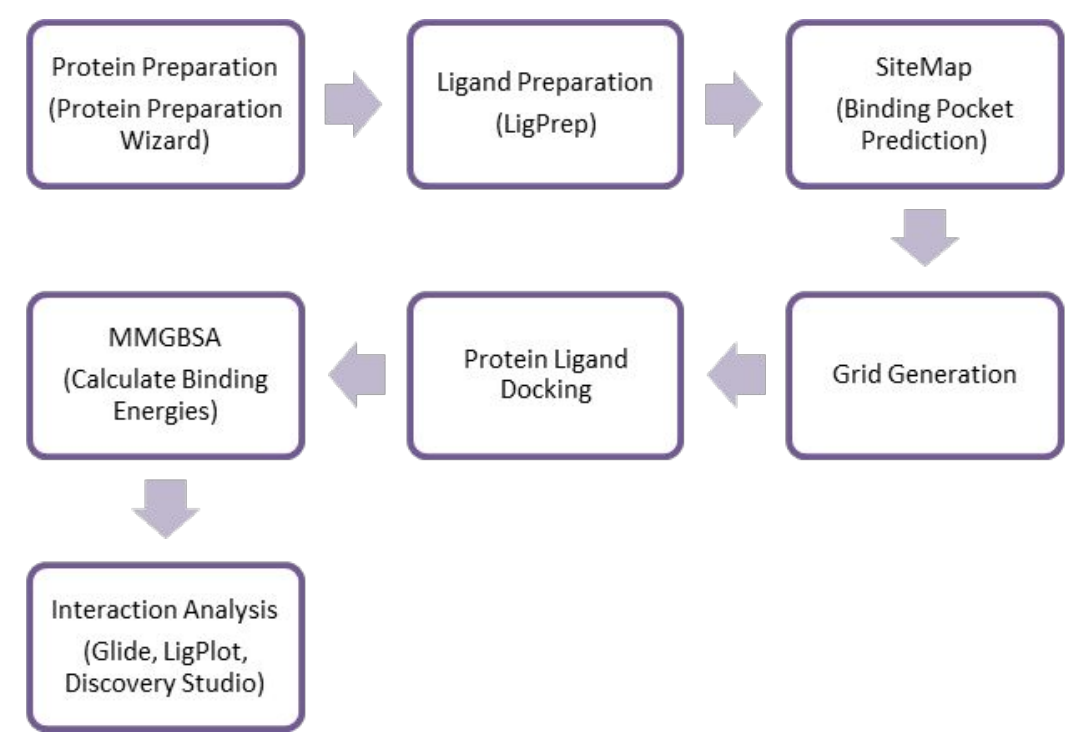

Figure S15: Docking simulation protocol followed for molecular docking
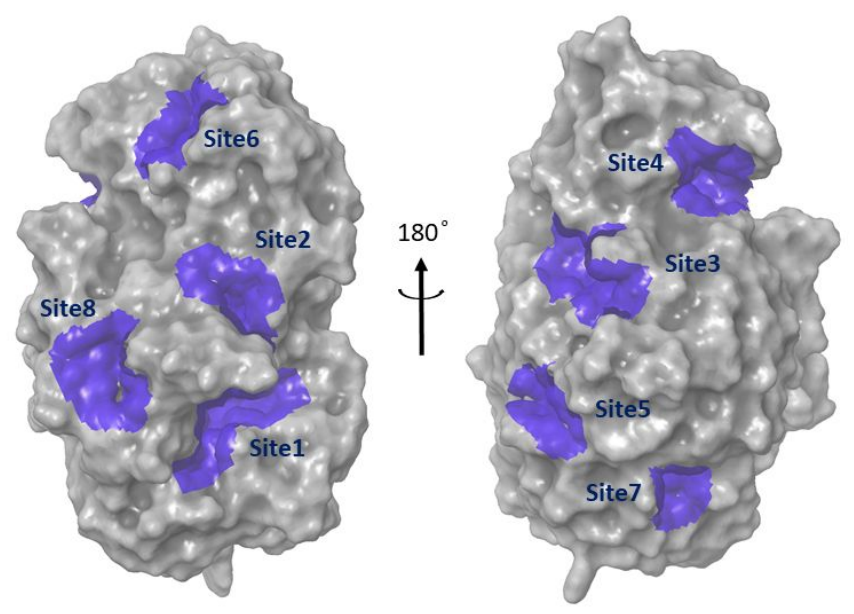

Figure S16: Solvent accessible surface rendering of HPA structure (2 orientations) showing the 8 pockets predicted by SiteMap. The surfaces representing the pockets are shown in blue colour while rest of the HPA surface is shown in grey. 


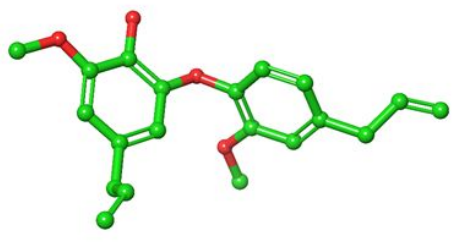

A

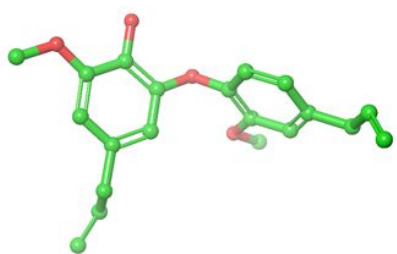

B

Figure S17: Two most stable conformers (A: Conformer 1; and B: Conformer 2) of DDEB generated in LigPrep process, shown as ball \& stick rendering. Green: Carbons, Red: Oxygens. (Hydrogens are not shown.) Conformer 1 (A) was used for detailed analysis of HPA-DDEB binding as it yielded better docking scores.

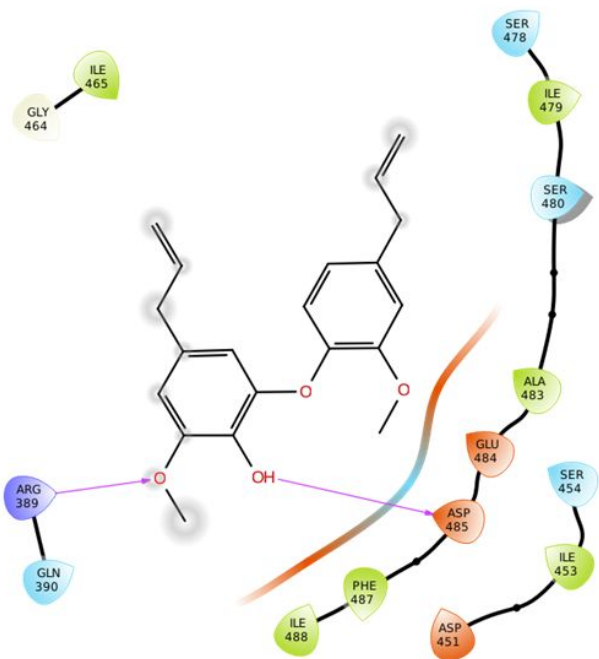

A

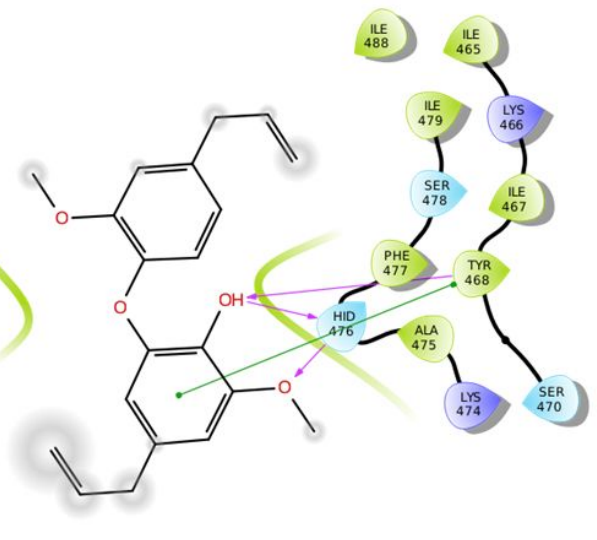

B

Figure S18: The 2D representation of HPA-DDEB interactions generated using Ligand Interaction Diagram utility in Glide interaction. A: Interactions in the binary HPADDEB complex and B: Interactions in the ternary HPA-Maltohexaose-DDEB complex. (Maltohexaose is not seen in the figure). Pink arrows indicate $\mathrm{H}$-bonds and the green straight line indicates pi-pi interaction. 
Supplementary Tables:

Table S1: PPA Inhibition of collected column fractions of silica 100-200 mesh column fractions (To be read with figure S1)

\begin{tabular}{|l|l|l|}
\hline Fraction & \% Yield & \% HPA inhibition \\
\hline 1 & 23.8 & 11.8 \\
\hline 2 & 4.0 & 32.3 \\
\hline 3 & 0.4 & 33.4 \\
\hline 4 & 4.0 & 87.2 \\
\hline 5 & 7.7 & 105.2 \\
\hline 6 & 2.8 & 31.6 \\
\hline 7 & 4.7 & 28.1 \\
\hline 8 & 23.2 & 22.5 \\
\hline 9 & 11.7 & 32.7 \\
\hline 10 & 17.6 & 2.8 \\
\hline
\end{tabular}


Table S2: Assignments and correlations of protons and carbons

\begin{tabular}{|c|c|c|c|c|}
\hline \multirow[b]{2}{*}{ Position } & \multicolumn{4}{|c|}{ Chemical Shifts (ppm) } \\
\hline & $\begin{array}{c}{ }^{1} \mathrm{H} \\
\mathrm{NMR}\end{array}$ & $\begin{array}{c}\text { HSQC } \\
\text { correlations }\end{array}$ & HMBC correlations & $\begin{array}{c}{ }^{13} \mathrm{C} \\
\mathrm{NMR}\end{array}$ \\
\hline 1 & - & - & - & 144.40 \\
\hline 2 & - & - & - & 131.06 \\
\hline 3 & - & - & - & 147.83 \\
\hline 4 & 6.49 & 107.25 & $\begin{array}{c}39.93(7), 111.86(6), 131.06(2), 135.19(5) \\
147.83(3)\end{array}$ & 107.25 \\
\hline 5 & - & - & - & 135.18 \\
\hline 6 & 6.40 & 111.86 & $39.93(7), 107.25(4), 135.18(5), 144.40(1)$ & 111.86 \\
\hline 7 & 3.24 & 39.93 & $\begin{array}{c}107.24(4), 111.86(6), 115.99(1), 131.06(2), \\
137.43(8)\end{array}$ & 39.91 \\
\hline 8 & 5.87 & 137.43 & $39.91(7), 135.18(5)$ & 137.43 \\
\hline 9 & 5.01 & 115.73 & $39.93(7), 137.43(5)$ & 115.73 \\
\hline 10 & 3.89 & 56.23 & $147.83(3)$ & 56.23 \\
\hline 1 ' & - & - & - & 144.20 \\
\hline 2 ' & - & - & - & 150.38 \\
\hline $3^{\prime}$ & 6.79 & 112.89 & 39.96(7'), 120.8(5'), 136.41(4'), 150.38(2’) & 112.89 \\
\hline 4 ' & - & - & - & 136.41 \\
\hline 5 & 6.71 & 120.83 & 39.96(7'), 112.8(3'), 119.40(6'), 144.20(1') & 120.83 \\
\hline 6 & 6.88 & 119.40 & $144.20\left(1^{\prime}\right), 150.38\left(2^{\prime}\right)$ & 119.40 \\
\hline 7 & 3.36 & 39.96 & $112.89\left(3^{\prime}\right), 120.83\left(5^{\prime}\right), 137.28\left(8^{\prime}\right)$ & 39.96 \\
\hline 8 ' & 5.96 & 137.28 & 136.41 (4'), 39.96 (7’), & 137.28 \\
\hline 9' & 5.08 & 115.99 & $39.96\left(7^{\prime}\right), 137.28\left(8^{\prime}\right)$ & 115.99 \\
\hline $10^{\prime}$ & 3.86 & 55.98 & $150.38\left(2^{\prime}\right)$ & 55.98 \\
\hline
\end{tabular}


Table S3: Docking scores and binding energies of the binary and ternary docked complex structures

\begin{tabular}{|c|c|c|c|c|c|}
\hline $\begin{array}{l}\text { Site ID } \\
\text { Scores }\end{array}$ & $\begin{array}{l}\text { Docking Score } \\
\text { (kcal/mol) }\end{array}$ & $\begin{array}{c}\text { G-score } \\
\text { (kcal/mol) }\end{array}$ & $\begin{array}{l}\text { Glide Emodel } \\
\text { (kcal/mol) }\end{array}$ & $\begin{array}{l}\text { Glide energy } \\
\text { (kcal/mol) }\end{array}$ & $\begin{array}{l}\text { MMGBSA- } \Delta \mathrm{G}_{\text {Binding }} \\
\quad(\mathrm{kcal} / \mathrm{mol})\end{array}$ \\
\hline \multicolumn{6}{|c|}{ The scores of two best binding sites of the HPA-DDEA binary complex } \\
\hline Site1 & -4.109 & -4.119 & -43.007 & -37.66 & -43.09 \\
\hline Site4 & -4.61 & -4.62 & -40.898 & -34.588 & -59.58 \\
\hline \multicolumn{6}{|c|}{$\begin{array}{l}\text { The scores of the best pose of DDEB bound at Site4 on the substrate-bound HPA co-crystal structure } \\
\text { (Ternary complex) }\end{array}$} \\
\hline Site4 & -5.742 & -5.752 & -43.337 & -32.467 & -59.84 \\
\hline
\end{tabular}

Table S4: Stabilizing Interactions between HPA and inhibitor complex at Site4

\begin{tabular}{|c|c|c|c|c|}
\hline Category & From & Chemistry & To & Chemistry \\
\hline \multicolumn{5}{|c|}{ (A) Interactions in HPA-inhibitor binary complex } \\
\hline \multicolumn{5}{|c|}{ Electrostatic Interactions } \\
\hline Hydrogen Bond & A:Arg389:NH1 & H-Donor & $\mathrm{X} 001: \mathrm{O} 3$ & H-Acceptor \\
\hline Hydrogen Bond & X001:H6 & H-Donor & A:Asp485:OD2 & H-Acceptor \\
\hline \multicolumn{5}{|c|}{ Hydrophobic interactions } \\
\hline \multicolumn{3}{|c|}{ Amino acid residues of $\mathrm{HPA}$} & \multicolumn{2}{|c|}{ Atoms of DDEB } \\
\hline \multicolumn{3}{|c|}{$\begin{array}{c}\text { A:Glu484 } \\
\text { A:Ala483 } \\
\text { A:Ser478 } \\
\text { A:Ile465 } \\
\text { A:Asp451 } \\
\text { A:Ser454 } \\
\text { A:Phe487 }\end{array}$} & \multicolumn{2}{|c|}{$\mathrm{C} 1-\mathrm{C} 20$} \\
\hline \multicolumn{5}{|c|}{ (B) Interactions in HPA-inhibitor ternary complex (in presence of substrate bound at active site) } \\
\hline \multicolumn{5}{|c|}{ Electrostatic Interactions } \\
\hline Hydrogen Bond & A:Tyr468:N & H-Donor & UNK1:O4 & H-Acceptor \\
\hline Hydrogen Bond & A:His476:N & H-Donor & UNK1:O3 & H-Acceptor \\
\hline Hydrogen Bond & A:His476:N & H-Donor & UNK1:O4 & H-Acceptor \\
\hline Pi-Pi Interaction & A:Tyr468 & $\begin{array}{c}\text { Aromatic ring } \\
\text { with } \pi \text { electrons }\end{array}$ & $\begin{array}{c}\text { UNK1:C8, C9, } \\
\text { C10,C11,C12,C13 }\end{array}$ & $\begin{array}{c}\text { Aromatic ring with } \\
\pi \text { electrons }\end{array}$ \\
\hline \multicolumn{5}{|c|}{ Hydrophobic interactions } \\
\hline \multicolumn{3}{|c|}{ Amino acid residues of HPA } & \multicolumn{2}{|c|}{ Atoms of DDEB } \\
\hline \multicolumn{3}{|c|}{$\begin{array}{l}\text { A:Ser478 } \\
\text { A::Ile465 } \\
\text { A::Ile467 } \\
\text { A:Ala475 } \\
\text { A:Lys466 }\end{array}$} & \multicolumn{2}{|c|}{$\mathrm{C} 1-\mathrm{C} 20$} \\
\hline
\end{tabular}




\section{References for Supporting information}

(S1) Costa-Silva, T. A.; Grecco, S. S.; de Sausa, F. S; Lago, J. H. G.; Martins E. G. A.; Terrazas C. A.; Varikuti, S.; Owens, K. L.; Beverley, S. M. Satoskar, A. R.; Tempone, A. G. Immunomodulatory and antileishmanial activity of Phenylpropanoid Dimers Isolated from Nectandra leucantha. J. Nat. Prod. 2015, 78(4), 653-657.

(S2) Miller, G. L. Use of dinitrosalicylic acid reagent for determination of reducing sugar. Anal. Chem. 1959, 31 (3), 426-428.

(S3) Nahoum, V.; Roux, G.; Anton, V.; Rougé, P.; Puigserver, A.; Bischoff, H.; Henrissat, B.; Payan, F.; Crystal structures of human pancreatic alpha-amylase in complex with carbohydrate and proteinaceous inhibitors. Biochem J. 2000, 346-1, 201-208.

(S4) LigPrep, Schrödinger, LLC, New York, NY, 2019.

(S5) Sastry, G. M.; Adzhigirey, M.; Day, T.; Annabhimoju, R.; Sherman, W. Protein and ligand preparation: parameters, protocols, and influence on virtual screening enrichments. $J$ Comput. Aided Mo.l Des. 2013, 27, 221-234.

(S6) Kaminski, G. A.; Friesner, R. A.; Tirado-Rives, J.; Jorgensen, W. J. J. Evaluation and Reparametrization of the OPLS-AA Force Field for Proteins via Comparison with Accurate Quantum Chemical Calculations on Peptides. J. Phys. Chem. B 2001, 105 (28), 6474-6487

(S7) Halgren T. New method for fast and accurate binding-site identification and analysis. Chem. Biol. Drug Des. 2007, 69,146-148.

(S8) Friesner, R. A.; Murphy, R. B.; Repasky, M. P.; Frye, L. L.; Greenwood, J. R.; Halgren, T. A.; Sanschagrin, P. C.; Mainz, D.T. Extra precision glide: docking and scoring incorporating a model of hydrophobic enclosure for protein-ligand complexes. J. Med. Chem. 2006, 49, 6177-6196.

(S9) Srinivasan J.; Cheatham III T. E.; Cieplak, P.; Kolman P. A.; Case, D. A.; Continuum Solvent Studies of the Stability of DNA, RNA, and Phosphoramidate-DNA Helices. J. Am. Chem. Soc. 1998, 120, 37, 9401-9409.

(S10) Homeyer, N.; Gohlke, H. Free energy calculations by the molecular mechanics PoissonBoltzmann surface area method. Mol. Inform. 2012, 31, 114-122.

(S11) Wallace, A.C.; Laskowski, R.A.; Thornton, J. M.; LIGPLOT: a program to generate schematic diagrams of protein-ligand interactions. Prot. Eng. 1995, 8, 127-134. 